This item was submitted to Loughborough's Research Repository by the author.

Items in Figshare are protected by copyright, with all rights reserved, unless otherwise indicated.

\title{
A platform for digital innovation in the management and administration of assessment and feedback
}

PLEASE CITE THE PUBLISHED VERSION

http://dx.doi.org/10.21125/iceri.2016.0885

PUBLISHER

IATED

VERSION

VoR (Version of Record)

\section{PUBLISHER STATEMENT}

This work is made available according to the conditions of the Creative Commons Attribution-NonCommercialNoDerivatives 4.0 International (CC BY-NC-ND 4.0) licence. Full details of this licence are available at: https://creativecommons.org/licenses/by-nc-nd/4.0/

\section{LICENCE}

CC BY-NC-ND 4.0

\section{REPOSITORY RECORD}

Lowery, Caroline A., and Melanie R.N. King. 2019. "A Platform for Digital Innovation in the Management and Administration of Assessment and Feedback". figshare. https://hdl.handle.net/2134/24899. 


\title{
A PLATFORM FOR DIGITAL INNOVATION IN THE MANAGEMENT AND ADMINISTRATION OF ASSESSMENT AND FEEDBACK
}

\author{
Dr C. Lowery-Spafford, M. King \\ Loughborough University (United Kingdom)
}

\begin{abstract}
This paper outlines a series of key developments and interventions that have enabled a platform for digital innovation in the management and administration of the assessment and feedback processes within a top 10 UK University.
\end{abstract}

The joined up platform of technological solutions and associated transformative staff practices demonstrated a wide impact on efficiency and productivity across the organisation. The initiative adopted new approaches to innovation and change to help deal with two major challenges:

1. Addressing the technical, organisational and cultural complexity of such a programme of work.

2. Addressing the challenge of limited resources with which to deliver lean, practical and useful digital solutions that can be efficiently and effectively adopted by staff and scaled up across the institution.

OUR CHALLENGE - Members of staff use a disparate set of learning technologies and desktop software to create and deliver assessments and to mark work and provide feedback to students. Each department and School tended to operate using a different set of procedures and forms to issue assessments and collect submissions, register participation and provide feedback. There was no clear and consistent mechanism to return work back to students or to check the consistency and quality of feedback. Individual practices and attitudes varied and academic staff needed to be convinced that new ways of working would be better for themselves and their students, especially with regards to adopting and accepting new technologies.

OUR APPROACH - This paper describes the pragmatic and agile way in which a small team set out to try and improve things one step at a time with the limited resources that were available to them. This initiative was a community driven activity taking an agile and very lean approach to change. It was recognised that changes to pedagogic and administrative practices, as well as development of a variety of digital solutions would be required.

THE SOLUTION - The digital platform developed (containing 5 components) comprises; features for assessment planning; communication; collecting data on submissions; collating data on feedback and returns; using the data to provide actionable insights in student engagement and staff practices; support a feedback dialogue between multiple staff and students; create a digital platform architecture underpinning multiple assessments, submissions and feedback types and applications; the creation of an assessment and submission data standard in order to join up data in disparate systems.

DIGITAL INNOVATION - All staff embraced new social and technical methodologies to address pedagogic practices and technical hurdles. 2014/15 marked a significant year in the process of development and adoption. The CASPA application became a mature, useful and highly used product. The roll-out of stand-alone kiosks and integration of assessment and submission data into the tutoring system Co-Tutor, was so successful, that adoption went from 4 departments to 9 in one year with minimal need for advocacy or support. Systems integration work via a data warehouse, creating a taxonomy for assessments, submissions and feedback data, is innovative in the sector allowing multiple learning technologies to 'talk to each other' effectively.

This paper will be of interest to practitioners and IT staff who are involved in the development, implementation and embedding of systems and process in their own universities. 
Keywords: innovation, learning technology, development processes.

\section{A NEED FOR CHANGE AND INNOVATION}

There is always too much demand on too little staff time, regardless of whether they are administrative, academic or technical. Staff within Higher Education (HE) are increasingly required to demonstrate 'value for money' in their work practices and tools used [1]. Historically staff have used a disparate set of learning technologies and desktop software to create and deliver university programmes. In 2011/12 at Loughborough University this myriad of technology and software coupled with the diverse range of policies and procedures used to administer assessment and feedback of student work came to the fore when existing departments were restructured and merged to become 10 schools. Each department had developed their own operating procedures and forms to issue assessments and collect submissions, register participation, provide feedback and communicate with students. There was no clear and consistent mechanism to return work back to students or to check the consistency and quality of feedback.

Individual practices and attitudes varied and academic staff needed to be convinced that new ways of working would be better for themselves and their students, especially with regards to adopting and accepting new technologies. In addition, the University sought to address findings from the National Student Survey ${ }^{1}$ (NSS) that continued to give lower satisfaction scores for assessment and feedback compared with other aspects of undergraduate study in HE [2]. To deal with the disparate ways of working and improve student satisfaction a series of small department projects were built upon and evolved into a mature institution-wide initiative.

\section{A COMMUNITY DRIVEN APPROACH}

\subsection{The contributors}

A number of staff and departmental teams collaborated and contributed to the programme of work from across the Engineering and Science departments, the Design School, the Centre for Engineering and Design Education (CEDE) and IT Services. Multiple teams comprising Associate Deans of Teaching, Programme Directors, Senior Departmental Administrators, Local IT and Network staff, Senior Tutors and Placement Co-ordinators, Departmental Office staff, a learning technologist, an ELearning systems manager and web developers also contributed to the process.

\subsection{The challenge of using limited development resources efficiently and effectively}

The initiative started as a department driven activity taking an agile and very lean approach to change. It was recognised from the outset that changes to pedagogic and administrative practices, as well as development of a variety of digital solutions would be required [3]. There was very limited IT development resource available, so to address this, the development team used a lean start up methodology. This meant that the only tools that were designed and built were those that could be tested rapidly and adapted quickly. This agile and lean approach ensured that development effort was not wasted. The project team also underpinned work by identifying the current processes in place in pilot departments as well as undertaking ongoing evaluation of technology and practice in order to scale up the initiative for all.

\subsection{Business requirements}

Table 1 indicates the key business requirements that were identified from the contributing community. The requirements gathered in an Agile 'as a, I want, so that' format spanned both staff and students needs and covered different sectors within the University itself.

\footnotetext{
${ }^{1}$ An annual survey completed by final year University undergraduates in the UK
} 
Table 1. Business requirements addressed

\begin{tabular}{|c|c|c|}
\hline As ... & I want ... & So that .... \\
\hline A student & $\begin{array}{l}\text {.. one place where I can find a } \\
\text { schedule of all of the assessments } \\
\text { due in for the forthcoming year and } \\
\text { have a record of my submissions. }\end{array}$ & $\begin{array}{l}\text {.. I can plan my time effectively and do } \\
\text { not have to navigate multiple systems. }\end{array}$ \\
\hline A busy student & $\begin{array}{l}\text {.. to be able to drop-off my work at } \\
\text { any time, day or night. }\end{array}$ & $\begin{array}{l}. . \quad \text { I can manage the multiple } \\
\text { commitments I have related to study, } \\
\text { work and home life. }\end{array}$ \\
\hline $\begin{array}{l}\text { A member of a } \\
\text { student group }\end{array}$ & $\begin{array}{l}\text {.. to know that any group } \\
\text { coursework I've contributed to is } \\
\text { still recorded as submission for me } \\
\text { and not just the person submitting } \\
\text { the work. }\end{array}$ & $\begin{array}{l}. . \text { I am reassured the work has been } \\
\text { handed in on time and all the group } \\
\text { members get notified about feedback. }\end{array}$ \\
\hline An administrator & $\begin{array}{l}\text {.. a less labour intensive and time } \\
\text { consuming way to collect physical } \\
\text { submissions and return the work to } \\
\text { the students. I also want to know } \\
\text { what items we are expecting in the } \\
\text { office. }\end{array}$ & $\begin{array}{l}. . \text { the collection process is efficient and } \\
\text { streamlined and the time saved can be } \\
\text { used to support the department in other } \\
\text { ways. }\end{array}$ \\
\hline A lecturer & $\begin{array}{l}\text {.. to avoid duplication of effort whilst } \\
\text { using multiple assessment and } \\
\text { feedback systems. }\end{array}$ & $\begin{array}{l}. . \text { I can maintain a variety of assessment } \\
\text { types to cater for different student } \\
\text { learning styles for example, physical lab } \\
\text { reports linked to sessions, online virtual } \\
\text { submissions and physical artefacts. }\end{array}$ \\
\hline $\begin{array}{l}\text { A Programme Co- } \\
\text { ordinator }\end{array}$ & $\begin{array}{l}. . \text { to review assessment loads and } \\
\text { edit due dates across the whole } \\
\text { programme of modules. }\end{array}$ & $\begin{array}{l}\text {.. subjects and teaching weeks with over } \\
\text { and under assessment can be identified } \\
\text { and any issues addressed. }\end{array}$ \\
\hline A Personal Tutor & $\begin{array}{l}\text {.. to know if my tutees are } \\
\text { consistently struggling to meet } \\
\text { submissions deadlines or not } \\
\text { addressing the same feedback they } \\
\text { constantly receive. }\end{array}$ & $\begin{array}{l}\text {.. I can provide academic guidance and } \\
\text { support in a timely and targeted way. }\end{array}$ \\
\hline $\begin{array}{l}\text { A Head of } \\
\text { Department }\end{array}$ & $\begin{array}{l}. . \text { to ensure that timely and } \\
\text { consistent quality feedback is } \\
\text { provided to all students. }\end{array}$ & $\begin{array}{l}. . \text { it is easier to identify both good } \\
\text { practice and modules that are in need of } \\
\text { improvement. }\end{array}$ \\
\hline $\begin{array}{l}\text { An Associate } \\
\text { Dean of Teaching }\end{array}$ & $\begin{array}{l}\text {.. to have a clear way to identify } \\
\text { persistent late or non-submitters. }\end{array}$ & .. timely intervention can be provided. \\
\hline The Director of IT & $\begin{array}{l}\text {.. to avoid a proliferation of } \\
\text { technologies } \\
\text { spreadsheets. }\end{array}$ & $\begin{array}{l}\text {.. the systems are robust and supported, } \\
\text { while maintaining data integrity and } \\
\text { security. }\end{array}$ \\
\hline
\end{tabular}

\section{DIGITAL INNOVATION AND SYSTEMS INTEGRATION}

The digital platform developed (components A-E) comprises features for assessment planning, communication, collecting data on submissions, collating data on feedback and returns, using the data to provide actionable insights into student engagement and staff practices. It supports a feedback dialogue between multiple staff and students through creating a digital platform architecture which underpins the multiple assessments, submissions and feedback types and applications. In addition, the creation of an assessment and submission data standard has been established in order to join up data in disparate systems.

A. The CASPA web application for creating, scheduling and managing assessments, physical submissions and returns.

B. Coursework submission physical kiosks.

C. Data feeds (Application Programming Interfaces (APIs)) providing integration between different assessment, tutoring and feedback applications. 
D. An enterprise architecture comprising an 'Assessment, Submission and Feedback Data Warehouse' (Fig. 1).

E. A universal taxonomy to describe disparate assessment, submission and feedback data pointers.

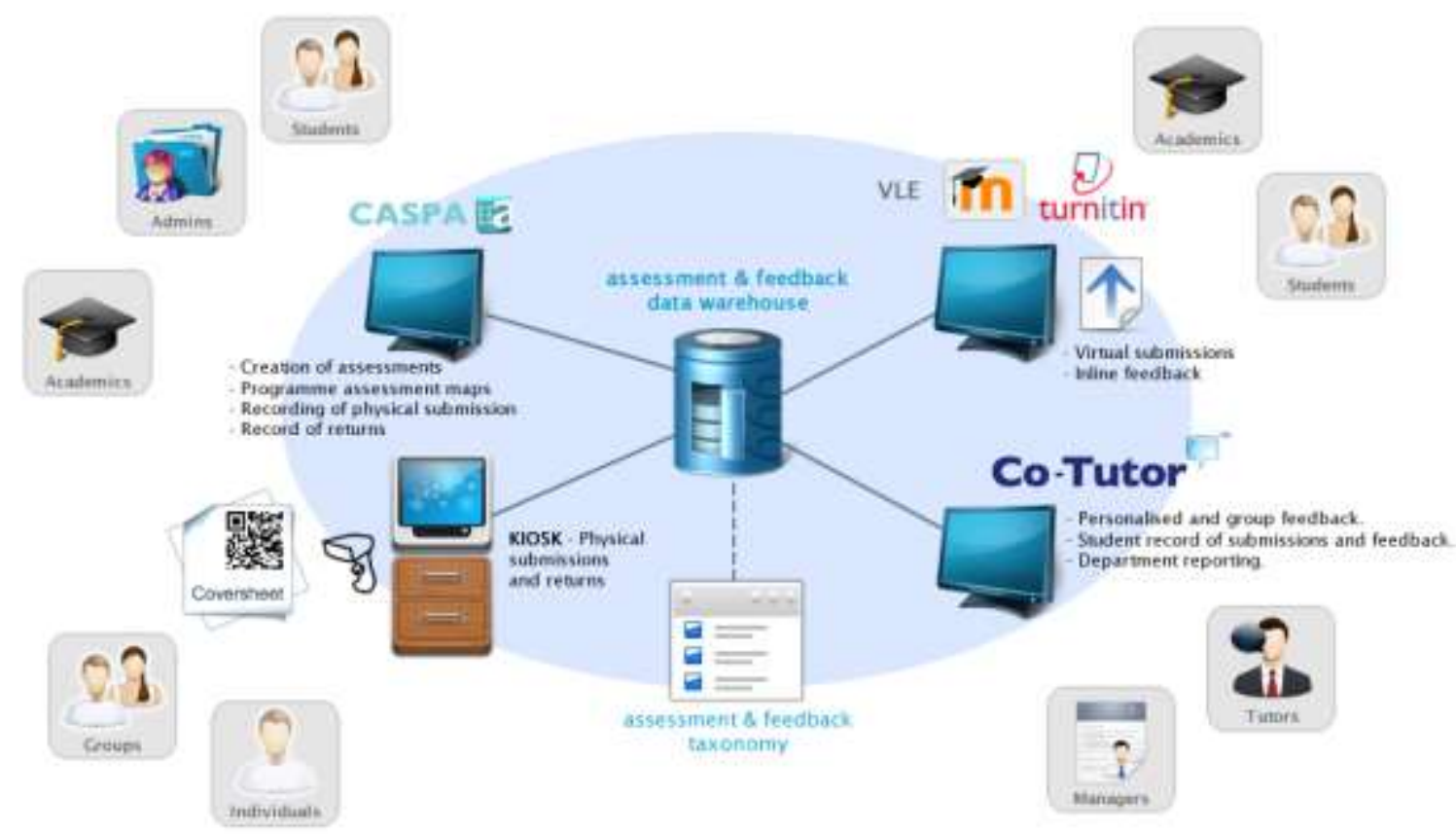

Figure 1 - The information architecture to support assessment and feedback management and administration $^{2}$

\subsection{The CASPA Application}

The Coursework and Assessment Scheduler for Programme Administration (CASPA http://caspa.lboro.ac.uk) [4] is used by academic staff, administrators and students (Fig. 2). It is a large PHP/MySQL web application, developed in-house. In 2014/15 interfaces were implemented, via the assessment and feedback data warehouse, to the University's Student Information System and other applications (Learn Virtual Learning Environment (VLE) and Co-Tutor®).

In its infancy CASPA was developed solely as a coursework submission tool to help with high demands on staff time for the submission of students' physical work within an individual engineering department. The successful use of CASPA, coupled with the need for a standardised approach within the newly formed Schools, initiated a growing demand for its use. In addition, the timely national findings from the NSS provided an opportunity for CASPA to be enhanced to provide a consistent mechanism to address issues raised by students regarding assessment bunching, overburdening and timely feedback.

\section{Main Features of CASPA}

- Staff can create and schedule different types of assessment within a module including physical, virtual, performance, examination, laboratory, workshop as well as using formative or summative stake indicators.

- Staggered assessments can be created to support work that is related to participation at repeated laboratories or performances etc.

- Assessment maps per year per programme (Fig. 3) help to show assessment bunching and allow programme directors to manage the assessment load on students.

- Each student can view a schedule of their own assessments including set dates, due dates, submission dates and expected feedback times.

- The CASPA application enables the management of physical submissions of work. A weekly view of the types of work due in, when it is expected and from how many students, can be viewed by administrators to aid in staffing submission desks.

- Each student receives an email receipt for any submitted work which includes details of timing and specific items submitted. 
- Student groups can easily create their own group coversheet. This self-selecting facility means that data on submissions for a whole group is recorded rather than the individual student who physically handed in the work. This eliminates the need to create spreadsheets of group information and saves a staff time wasted in creating and tracking groups.

- CASPA manages the handing back of work to students recording who has picked up their coursework and when.



Figure 2 - The CASPA application -virtual assessments in Civil and Building Engineering

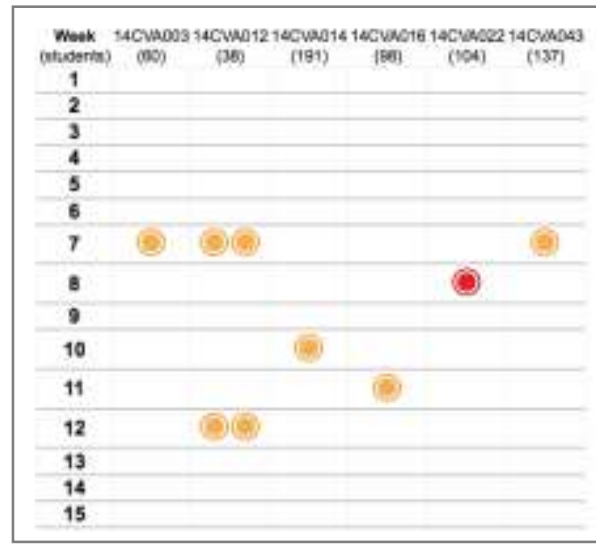

Figure 3 - Assessment map for a programme

\subsection{The CASPA Kiosk - a physical coursework drop box}

An Quick Response (QR) reader and PC form the key components of the CASPA Kiosks located in each School and used by students and staff to submit and return physical submissions of student work.

- A coursework coversheet, printed by students for each submission, contains an automatically generated unique Quick Response (QR) code which is attached to the student's work. Students scan the QR code to register their submission. Students can drop off their work at any time of the day on any day of the week (24/7) up until the submission deadline using the stand-alone kiosks located around the campus. 
- CASPA emails a receipt to each student even if the work submitted is a group piece of work.

- The same QR coversheet is also scanned to provide a formal mechanism to record the return of work back to students.

\subsection{Integration between applications}

Once a CASPA assessment is linked to a virtual submission mechanism, for example Turnitin (Fig. 4), information about any submissions and any inline feedback given is recorded in the data warehouse to enable holistic reporting. A CASPA ID is used to provide the link between Turnitin/Learn and CASPA.

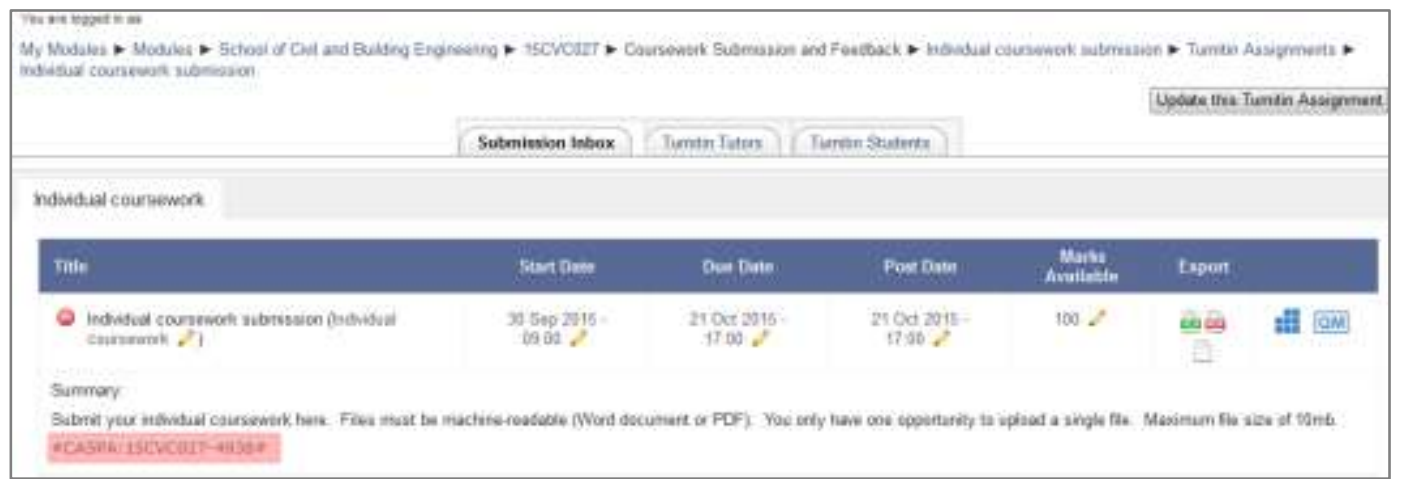

Figure 4 - A CASPA ID added to the VLE 'Learn' (Moodle or Turnitin assignment) enables data on submissions and feedback to be linked between the systems.

Co-Tutor is a staff and student relationship management system which also provides a dashboard of information and reports on student engagement for personal tutors, project supervisors, placement supervisors and department managers. It is a PhP/MySQL application and has been developed in house. In 2014/15 Co-Tutor became integrated with the data warehouse and receives submission and feedback data from CASPA, Learn and Turnitin via the data warehouse.

\section{Main assessment and feedback features in Co-Tutor}

- Details of a student's assessment schedule along with details of the time of submission (for physical hand-ins) are all available in a student's record which can be seen by their personal tutor.

- Module tutors can create feedback to students for any type of CASPA submission, along with an indication of progress, which can also be seen by their personal tutor (Fig. 5).

- Reports on submissions received for a department, programme or module can be viewed (Fig. 6).

- Reports on a per module basis can also be viewed showing late, on time and non-submissions for the cohort (Fig. 7).

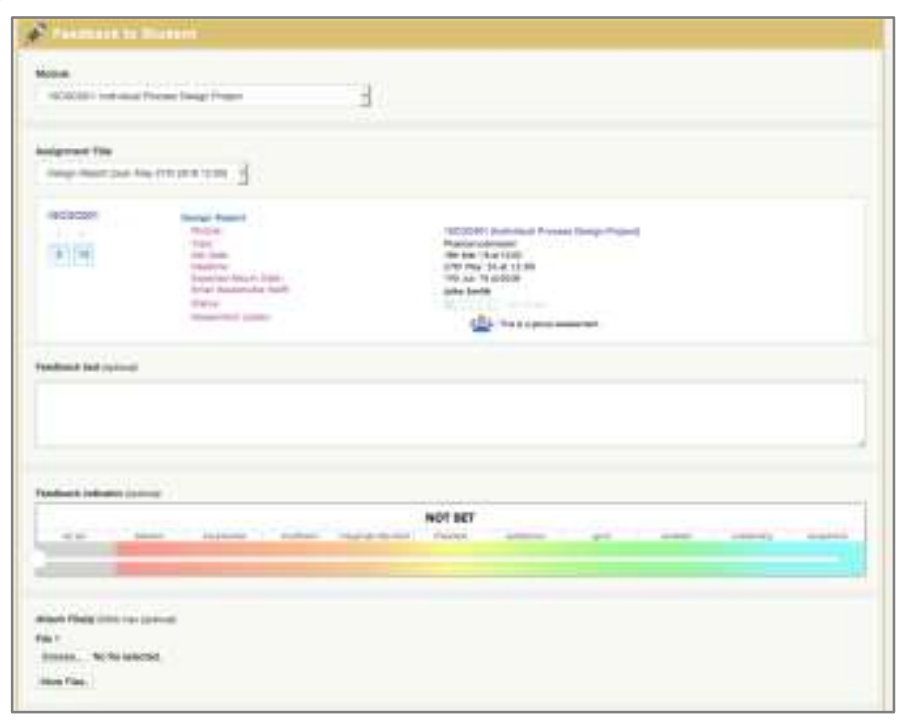

Figure 5 - Creating feedback through Co-Tutor for any type of assessment 


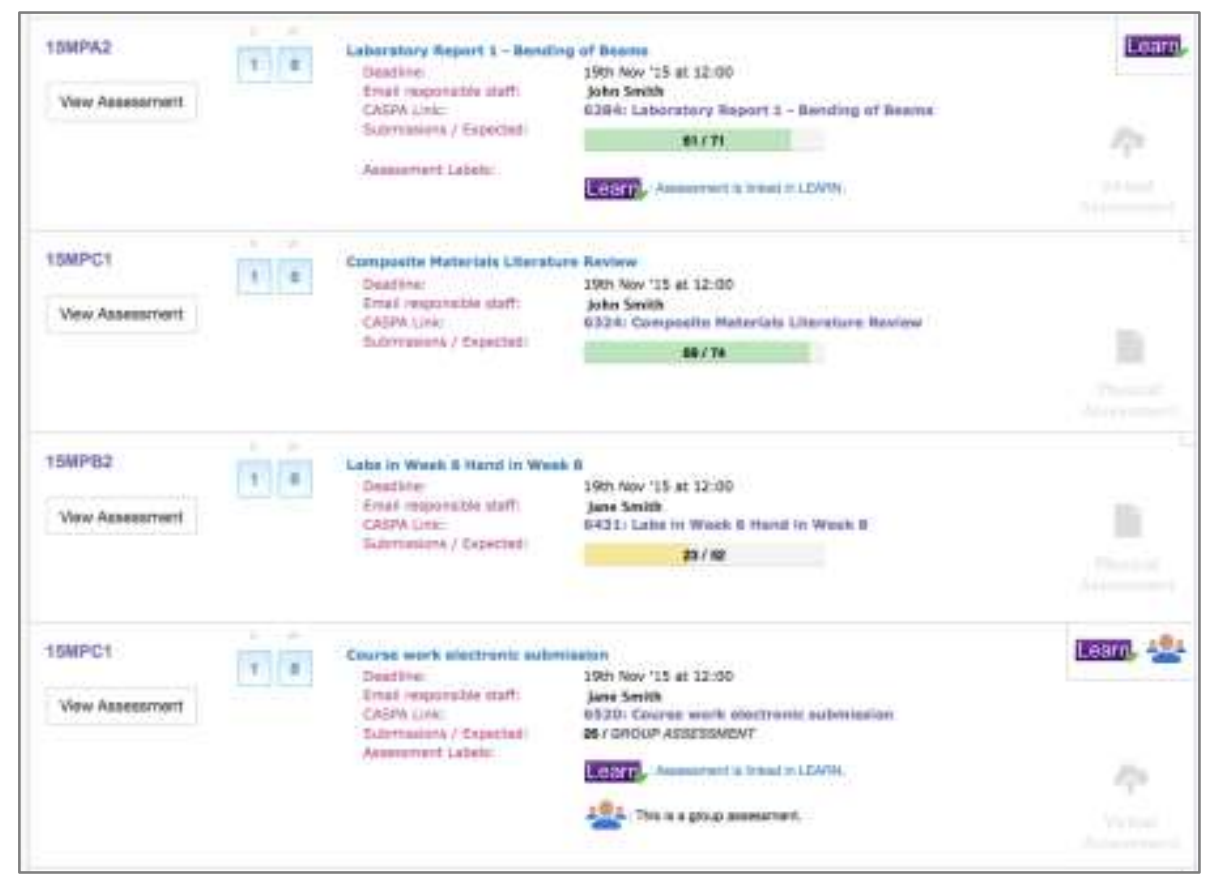

Figure 6 - Assessment and submission information for course

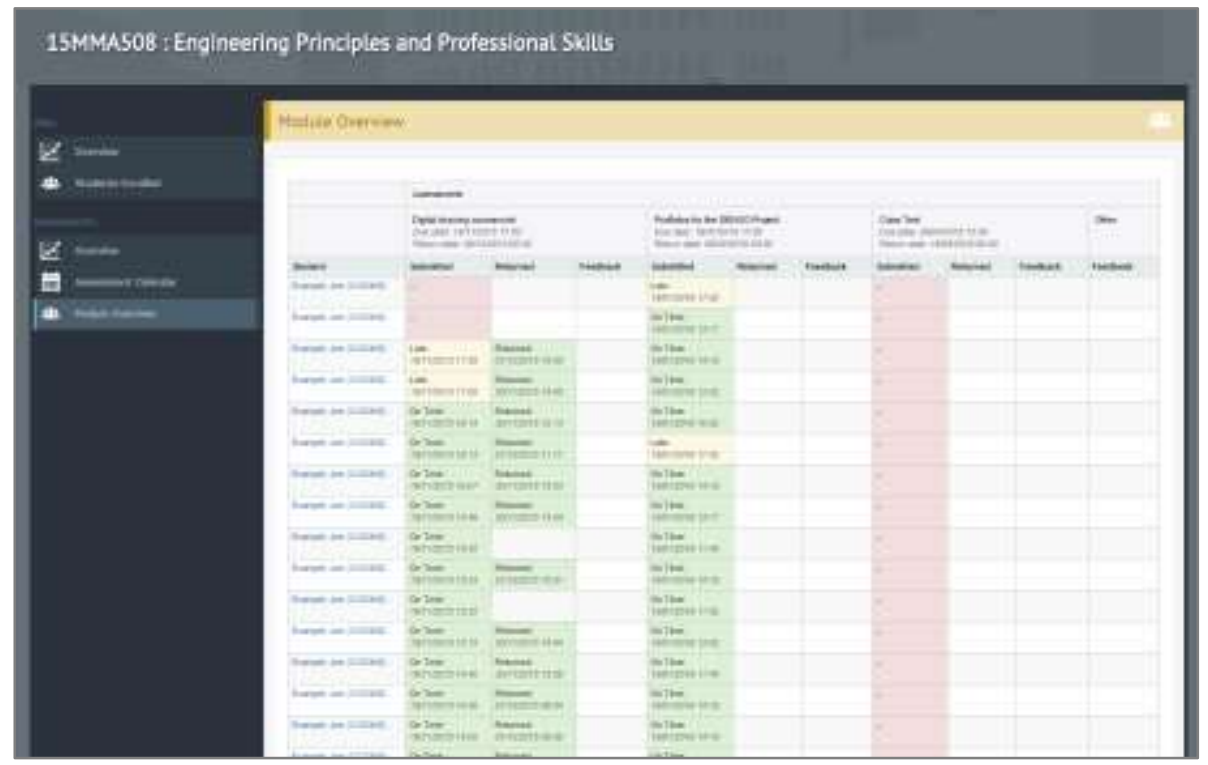

Figure 7 - Assessment and submission report for module.

\subsection{Assessment, Submission and Feedback Data Warehouse and Taxonomy}

In 2014/15 the data warehouse was implemented (Fig. 8), which integrates information between all the assessment systems on campus based on our assessment and feedback taxonomy. The warehouse provides the central point were all the latest data is stored and from where the relative systems (CASPA, Co-Tutor and Learn/Turnitin) retrieve their required data. 


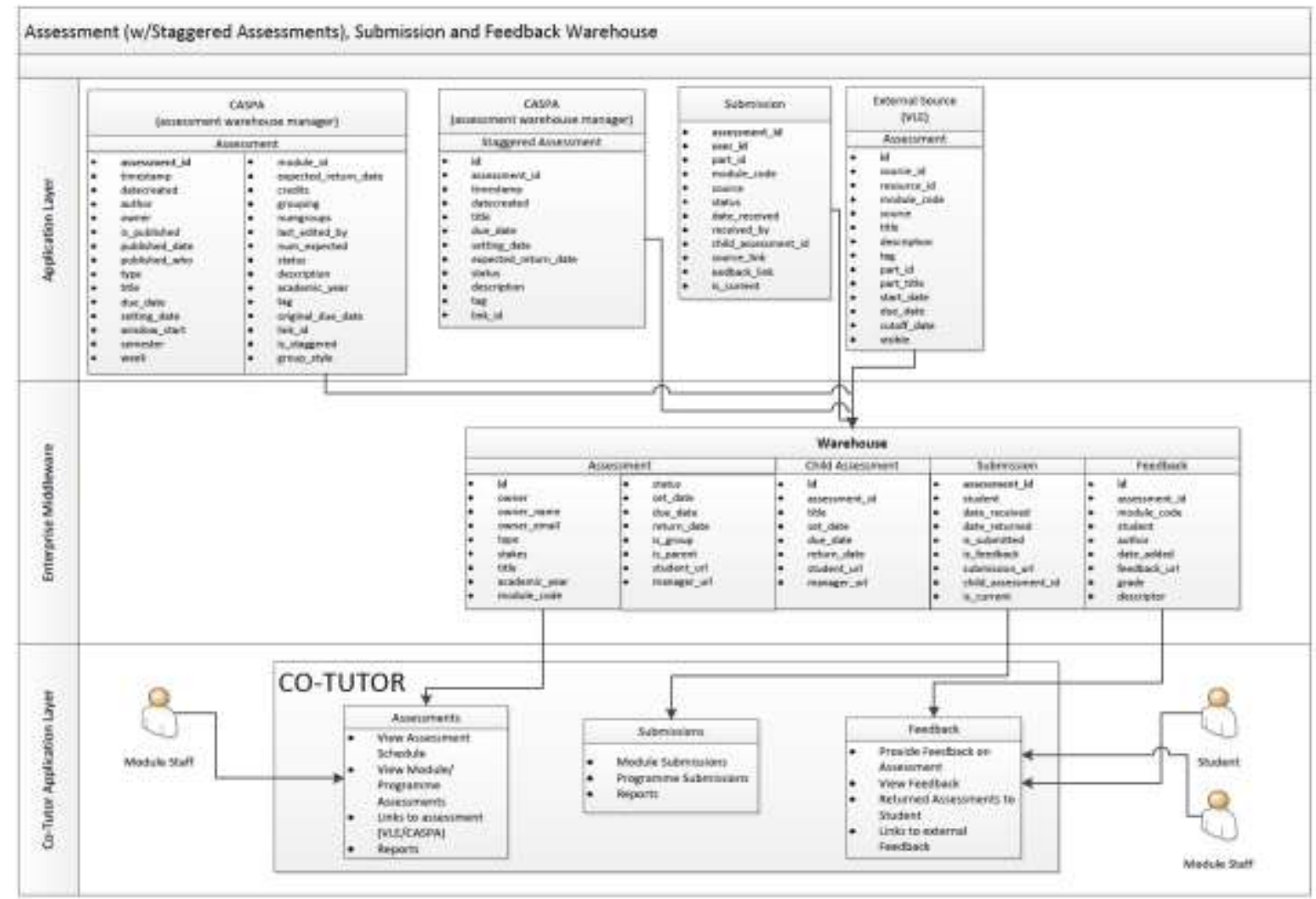

Figure 8 - Information architecture of the data warehouse and feeding systems.

\section{FINDINGS}

The gathering of user-requested enhancements and additions to the systems and their prioritisation was managed carefully in order to ensure that the solution was as efficient and user friendly as possible across the University. Development work undertaken meant that all of the original business requirements could be met and the usage statistics in Table 2 demonstrate the significant uptake in the use of CASPA within the University over the last few years.

Table 2 - Adoption of CASPA within the University

\begin{tabular}{|l|l|l|}
\hline & \multicolumn{1}{|c|}{ 2014/15 } & \multicolumn{1}{|c|}{ 2015/16 } \\
\hline Departments & 9 & 11 \\
\hline $\begin{array}{l}\text { Staff assessment } \\
\text { owners }\end{array}$ & 339 & 395 \\
\hline Students affected & 5557 & 7306 \\
\hline Total assessments & 1773 & 1862 \\
\hline Assessments by type & $\begin{array}{l}1168 \text { Physical submissions, 244 } \\
\text { Virtual submissions, 474 other. }\end{array}$ & $\begin{array}{l}1037 \text { Physical submissions, } 497 \\
\text { Virtual submissions, 372 other. }\end{array}$ \\
\hline Number of modules & 708 & 835 \\
\hline Total submissions & 43,325 & 53,598 \\
\hline Kiosk submissions & $32,326(75 \%)$ & $24,506(46 \%)$ \\
\hline
\end{tabular}

Addressing the issues found in the user stories has enhanced efficiency and productivity in 8 key themes. These themes emerged from focus groups of 12 administrators together with surveys of staff and 88 students throughout the University. 


\section{Integration of learning technologies}

- The integration of technologies mitigates the duplication of data in multiple systems and automates the collection of submission information whether virtual or physical providing a more integrated experience for staff.

2. Flexibility for students

- Students can drop off their work at any time via the kiosks without the need to queue and sign receipts.

3. Saving staff time

- Students create their own individual or self-selecting group coversheets removing the need for spreadsheets.

- Programme Leaders view course assessment maps in a single place eliminating the need to search multiple sources.

- Assessments are rolled-over each year, with only the due date requiring editing therefore data is entered just once.

- Un-manned QR kiosks now account for the majority of hand-ins, freeing up staff time which allows them to engage in quality assurance and improvement activities.

4. Consistent experience for students

- There is one view of an assessment schedule and the use of the same coversheet for submission and return of work.

5. Consistent staff practices

- All information on assessments is gathered early, in the same format, following the same process all the way through the assessment and feedback life cycle.

6. Capability to allow for staggered assessments linked to laboratory attendance

- Managing staggered hand-ins associated with different laboratory sessions eliminates the huge admin burden.

7. A holistic data set on all assessment and submissions

- The creation of the data warehouse, as a hub for disparate technologies, mitigates the duplication of data.

- Paperwork circulated relating to assessment management is now the bare minimum, reducing the chances of error.

\section{Providing the right reports and communications to the right people}

- Reports provided in Co-Tutor can give an insight into overall student engagement and also staff practices to allow for timely follow up to support both students and staff where necessary.

- It is quick and easy to send out targeted communications to students and record this on their file.

\section{CONCLUSIONS}

Working with key users for CASPA, Learn and Co-Tutor systems has been instrumental in developing enhancements and systems' interoperability and has helped to ensure a user focused solution. Working closely with key users and understanding their user stories has provided a sound mechanism to aid the evaluation of the systems as they continue to evolve. Maintaining this user centred approach in the future is fundamental to the acceptance and uptake of the systems throughout the University.

This initiative has embraced new methods to integrate activities that address cultural issues alongside agile technical development. The last few years have marked a significant increase in the process of development and adoption. CASPA has become a mature, useful and highly used product. The work to roll-out stand-alone kiosks and integrate the data on submissions and assessment schedules into the tutoring system Co-Tutor was so successful that adoption went from 4 departments to 9 in one year with minimal need for advocacy and support. The ability to integrate systems via a data warehouse underpinned by the creation of a taxonomy for assessments, submissions and feedback data, will be useful for other universities who are working towards an information architecture for assessments and feedback.

\section{Staff Testimonials}

"We have found the CASPA system has completely changed our lives and for the better! We would highly recommend this system to other universities." Pam Allen, MSc Postgraduate Programme Administrator, School of Civil and Building Engineering. 
"It has enabled records to be accurate and useful, enabling a small team of administrators to offer a more effective service to students and to help ensure that feedback is returned in a timely manner. Feedback we have received from our students indicates they are very happy with the hand-in and hand-back sessions and they have commented on the improvements in the service, which is appreciated by all staff." Sarah Rate, School Administrator, School of Civil and Building Engineering.

\section{ACKNOWLEDGEMENTS}

${ }^{1}$ An annual survey completed by final year University undergraduates in the UK

${ }^{2}$ Icons used from http://www.iconarchive.com - authors: Toma4025, Icons8, Oxygen Team, used within terms of license.

\section{REFERENCES}

[1] C. Whitchurch, "Beyond administration and management: reconstructing the identities of professional staff in UK higher education," Journal of Higher Education Policy and Management, Vol. 30, no. 4, pp.375-386 2008

[2] Higher Education Academy, "HEA Feedback Toolkit," HEA, York, UK, 2013. Available at: https://www.heacademy.ac.uk/sites/default/files/resources/feedback toolkit whole1.pdf [Accessed on 4th September 2016]

[3] P. Abrahamsson, O. Salo, J. Ronkainen, and J. Warsta, "Agile software development methods: Review and Analysis," Espoo, Finland: Technical Research Centre of Finland, VTT Publications, 478, 2002. Available online: http://www.vtt.fi/inf/pdf/publications/2002/P478.pdf [Accessed on 4th September 2016]

[4] C. Lowery and S. Bamforth, "CASPA: Coursework and Assessment Scheduler for Programme Administration," in $10^{\text {th }}$ International Technology, Education and Development Conference, Valencia, Spain, 7-9 March 2016. INTED 2016. pp. 4462-4469, 2016 